\title{
Opgøret med diversitetsdiskurs
}

\author{
Ahmed, Sara: \\ Et Ulydigt Arkiv \\ Forlaget Nemo, 2020, 208 sider. Pris: 240 kr.
}

\author{
Af Tess S. Skadegård Thorsen \\ Ph.d., Undervisningsassistent, Center for Køn, Seksualitet \& Forskellighed, KU
}

\section{Ahmed på dansk}

På et lille forlag i et lille land er et lille oversætter-kollektiv lykkedes med at gøre nogle af nutidens vigtigste undertrykkelses-teoretiske tekster tilgængelige på dansk. Det drejer sig om en samling kortere tekster, både essays og artikler, af kultur-, race-, diversitets-, køns- og queer-forskeren Sara Ahmed, udgivet under titlen Et Ulydigt Arkiv.

Ahmeds forskning har fået global opmærksomhed i de seneste årtier, og hendes akademiske stjernestatus blev ikke forringet, da hun gjorde teori til virkelighed og trådte tilbage fra sin stilling på Goldsmiths University i solidaritet med studerende ramt af seksuelle krænkelser/sexchikane. Hendes forskning har også fået sit indtog i den danske kontekst, især som følge af forskerkollektivet Peculiars hyppige citering af hende. Derfor er det også et passende valg, at to af kollektivets medlemmer, Mons Bissenbakker og Michael Nebeling, leverer et kontekstualiserende forord som introduktion til værket.
I den danske kontekst er det primært Ahmeds affektteoretiske arbejde, der hidtil har vundet indpas. Affektteoriens anvendelighed i Danmark tydeliggøres også af Bissenbakker og Nebelings indledningsvise analyse af ghettoloven: "Den hyperbole fremskrivning af faren og utrygheden i "ghettoerne" konkretiseres i udspillet til frygten for "bander og kriminelle", der, som racialiserede betegnelser, på en gang intensiverer angsten og samtidig giver den retning og genstand" (s.18).

Det er en gave, at bogen både indledes af et forord af nogle af de danske forskere, der har haft primær indflydelse på Ahmeds anvendelse og udbredelse i Danmark, og samtidig også tilbyder læseren et forord af Ahmed selv. Ahmed fremhæver $\mathrm{i}$ eget forord en gennemgående tråd i de valgte tekster, som vil være helt central for danske læsere; produktionen og genkendelsen af den fremmede. Heri får vi også en lille smag på de dele af Ahmeds tankegods som stadig fortjener tættere læsninger i Danmark, og som heldigvis med denne oversættelse måske vil opnå netop dette. 


\section{Ulydige læsninger}

Ahmed er nemlig en forrygende tænker inden for kritiske hvidhedsstudier, racialiseringsforskning og kritisk raceteori, og både teksterne "Hvidhedens fænomenologi" og "Hvidhedserklæringer: Antiracismens ikke-performativitet" fortjener en genlæsning på dansk, i forbindelse med de spæde skridt der i disse dage tages til etablering af kritiske hvidhedsstudier i Danmark. Hvis dansk hvidhedsforskning skal bevæges forbi et argument om differentieret hvidhed (hvad Ahmed kendetegner som tidlige hvidhedsforskeres ængstelighed ved at gøre hvidhed "essensbærende", s. 59), er det dermed nødvendigt med kritiske bearbejdninger af positionalitet og magt, også blandt de få eksisterende hvidhedsforskere i Danmark.

Det er imidlertid Ahmeds banebrydende arbejde omkring institutioner, diversitets-politik (og -arbejde) og klager, som for alvor vækker genklang i forhold til mit eget forskningsområde, og som ligeledes med fordel kunne antænde en nødvendig kritik af dansk (forskning i) arbejde med diversitet og anti-racisme i institutioner.

Der er - især i forhold til den danske hyperfokusering på distraktionsordet "krænkelseskultur" - nemlig meget at hente i Ahmeds arbejde med klager, i forhold til de verserende debatter og undertrykkelsesmekanismer på danske uddannelsesinstitutioner, både i relation til studerende og $\mathrm{i}$ relation til ansatte i udsatte og politiserede forskningsområder. Det centrale argument, der her går igen, er, at vi må undersøge, hvad der sker, når den klagende bliver gjort til problemet - snarere end hvad der klages over: "Ordet 'klagende' har en negativ klang. Det tilhører den samme familie af ord som glædesdræberen: Klagende, klynkende, jamrende, stivstikker, lyseslukker, glædesdræber." (s.50)

Denne ( $\mathrm{i}$ en dansk kontekst) ofte mere oversete del af Ahmeds forskning skriver sig ind $i$ en bred international kritik af diversitets- og mangfoldighedsarbejde, som påpeger, hvordan diversitets-diskurs og multikulturalisme effektivt kan erstatte eller marginalisere mere dybdegående analyser af ulighed og undertrykkelse. I England er eksempelvis forskerne Anamik Saha, Sarita Malik og Clive Nwonka alle med til at fremme denne kritiske analyse af diversitets-diskurs i forlængelse af Stuart Halls kritiske Birmingham-skole-kulturteori (Malik, 2013; Nwonka, 2020; Nwonka \& Malik, 2018; Saha, 2018). I min egen forskning har jeg for nyligt vist, hvordan dette udfolder sig i den danske filmbranche, hvor 'berigelse' og 'diversitet' udgør fremtrædende diskurser (Skadegård Thorsen, 2021).

Ahmeds analyser skaber således brugbare værktøjer til analyser på tværs af køns-, queer-, crip-, race- og klasse-teori (og langt mere). Arkivet i bogen er teoretisk ulydigt, ligesom det modsætter sig en hierarkisering af Ahmeds forfatterskab, ved ikke kun at anderkende og kanonisere Ahmeds peer-reviewede forskning eller affekt-teoretiske forfatterskab.

\section{Obligatorisk læsning}

Ahmed er kendt for at være en ordsmed og benytter sig ofte intentionelt af ord med merbetydning eller flere betydninger. Det må have været en utaknemmelig opgave, at skulle oversætte hendes ofte nørklede og spillende sprog til dansk. Derfor er det også en fornøjelse, at man som læser foræres en del oversættelsesteknisk indblik i de beslutninger og konsekvenser, oversættelsesarbejdet medvirker: Flertydige begreber er markeret med klammer [brackets], og noter angives sideløbende i tekstens margin, hvilket bidrager til en gnidningsfri læseoplevelse.

Det er et centralt og brugbart værk med anvendelighed på tværs af fagområder. Selv kan jeg se anvendelighed på vores kurser på Center for Køn, Seksualitet og Forskellighed, hvor en stor del af teksterne allerede fremgår på pensa i deres engelske originaler, og hvor de studerende jævnligt efterspørger danske tekster. Anmelder-kollektivets positionalitetsrefleksioner og forsigtighed tydeliggøres i deres efterord, som man skal sikre sig at læse med. 


\section{Litteratur}

Malik, S. 2013. "Creative diversity”: UK public service broadcasting after multiculturalism. Popular Communication, 11(3), 227-241.

Nwonka, C. J. 2020. The new Babel: the language and practice of institutionalised diversity in the UK film industry. Journal of British Cinema and Television, 17(1), 24-46.

Nwonka, C. J., \& Malik, S. 2018. Cultural discourses and practices of institutionalised diversity in the UK film sector:'Just get something black made.' The Sociological Review, 0038026118774183.

Saha, A. 2018. Race and the cultural industries. Cambridge: Polity Press.

Skadegård Thorsen, T. S. 2021. "Enriching Danish Film with Cultural Diversity": Danish representational politics through the lens of the Danish Film Institute (DFI). In C. J. Nwonka \& A. Saha (Eds.), Black Film, British Cinema II (Forthcoming) (p. 228). London: Goldsmiths Press, MIT Press. 